(1969) found that young platelets have a shorter aggregation time after the addition of adenosine diphosphate. The minor increase in adhesiveness that we found when using plateletrich plasma may well reflect a change in platelet population after blood loss.

Reticulocyte counts were not carried out on the blood samples tested. It was thought unlikely that there would be any significant change in healthy persons eight days after donating $500 \mathrm{ml}$ of blood, and that this index would not be sufficiently sensitive to measure the shift in red cell population which we consider causes the changes in adhesiveness. Reticulocytosis indicating an obvious increase in young red cells might well influence platelet adhesiveness, and we have been carrying out further experiments and collecting data on patients with an increase in reticulocytes.

Any estimation of postoperative changes in adhesiveness, especially when using a whole blood method, must be interpreted with due regard to the degree of blood loss in the patient as it is apparent that this by itself can produce increased adhesiveness. It is likely that the more severe the blood loss the greater the expected increase in adhesiveness, this probably depends on the number of young red cells in the peripheral blood as well as the increase in young platelets.
After operation there is an increase in platelet adhesiveness as well as an increase in venous thrombosis. It would be of interest to know whether adequate replacement of blood loss at operation with suppression of marrow activity would reduce this increase in adhesiveness with associated venous thrombosis.

We should like to thank the Red Cross blood donors who kindly consented to take part in these investigations and Professor D. L. Mollin who agreed that we might ask the donors to assist. We wish to thank Mrs. Sylvia Wolff. Miss Angela de Jong. and Miss Charis E. Jocelyn for skilled technical help. We are grateful to the Subcommittee for Clinical Research, Charing Cross Hospital, for financial support.

Requests for reprints should be addressed to Dr. Sidney Shaw.

\section{References}

Bennett, P. N. (1968). Fournal of Clinical Pathology, 21, 695.

Hellem, A. J. (1960). Scandinavian Fournal of Clinical and Laboratory Investigation, 12, Suppl. No. 51.

$\mathbf{K}$ arpatkin, S. (1969). Fournal of Clinical Investigation, 48, 1083.

Shaw, S., Pegrum, G. D., and Wolff, S. (1970). Fournal of Clinical Pathology,

23, 144.
Wright, H. Payling (1942). Fournal of Pathology and Bacteriology, 54, 461.

\title{
Radioimmunoassay of Human Serum Thyrotrophin
}

\author{
REGINALD HALL, JACQUELINE AMOS, BRIAN J. ORMSTON
}

British Medical fournal, 1971, 1, 582-585

\section{Summary}

The double antibody radioimmunoassay of serum thyroidstimulating hormone (TSH) allows measurement of circulating levels of the hormone in most normal subjects. The serum TSH level in normal subjects is $1.6 \pm 0.8 \mu \mathrm{U} / \mathrm{ml}$. Patients with non-toxic goitre and acromegaly have normal TSH levels. Values are always raised in hypothyroid patients (with primary thyroid disease) and are significantly lowered in those with hyperthyroidism. Of the many stimuli used in an attempt to raise TSH levels in normal adult subjects only three-synthetic thyrotrophin-releasing hormone, ethinyloestradiol, and carbimazole plus iodides-have been effective. The major clinical application of the TSH immunoassay lies in the diagnosis of minor degrees of hypothyroidism. An impaired response of serum TSH to synthetic thyrotrophinreleasing hormone should also help in the diagnosis of hypopituitarism affecting TSH production.

\section{Introduction}

Specific radioimmunoassays of human thyroid-stimulating hormone (TSH) have been described by Odell et al. (1965), Utiger (1965), and Webster and Greenwood (1968). So far there have been only brief reports of the results of TSH

\footnotetext{
Department of Medicine, University of Newcastle upon Tyne, Newcastle upon Tyne NE1 4LP

REGINALD HALL, M.D., F.R.C.P., Professor of Medicine

JACQUELINE AMOS, Chief Technician

BRIAN J. ORMSTON, M.B., B.S., Research Fellow
}

immunoassays in normal subjects and patients with various thyroid diseases from the U.K. (Hall et al., 1970a; Kirkham et al., 1970; Hall and Amos, 1971). Now that the materials required for the TSH immunoassay are readily available it seems likely that the method will be adopted in most major centres. This report outlines our current double antibody immunoassay for TSH and describes its clinical and physiological applications.

\section{Materials and Methods}

Reagents.-Human TSH supplied by the National Pituitary Agency is used for iodination. Standard human TSH is obtained from the Medical Research Council (M.R.C. Standard A). Initially rabbit anti-TSH antisera obtained from the National Pituitary Agency and from Professor D. Munro were used. Results presented here, however, are derived from the use of a guinea-pig anti-TSH antiserum prepared in Newcastle with TSH fraction DEAE II supplied by Dr. A. Hartree. This antiserum has a higher specificity and avidity than currently available rabbit antisera. Rabbit anti-guinea-pig gammaglobulin was produced locally and tested against ${ }^{131}$ I-labelled guinea-pig gammaglobulin. At the dilution $(1 / 10)$ used in the assay more than $90 \%$ of labelled gammaglobulin can be precipitated after overnight incubation.

Iodination Procedure.- ${ }^{131}$ I labelled TSH is prepared by the chloramine-T method of Hunter and Greenwood (1962) with Amersham IBS 3 carrier-free ${ }^{131}$ I. Five microgrammes of TSH in $10 \mu \mathrm{l}$ of $0.01 \mathrm{M}$ phosphate buffer $\mathrm{pH} 7.4$ is added to $2 \mathrm{mCi}$ of ${ }^{131} \mathrm{I}$, followed by the addition of $50 \mu \mathrm{g}$ of chloramine-T in $10 \mu \mathrm{l}$ and then sodium metabisulphite $250 \mu \mathrm{g}$ in $100 \mu \mathrm{l}$. After removal of an aliquot of the iodination mixture for electrophoresis, 131 Ilabelled TSH is purified by a modification of the method of Yalow and Berson (1966). Amberlite IRA 400 (Cl) is added to remove ${ }^{131} \mathrm{I}$ and, after separation, $50 \mathrm{mg}$ of Quso is added to the supernatant to adsorb undamaged TSH. The Quso is washed four 


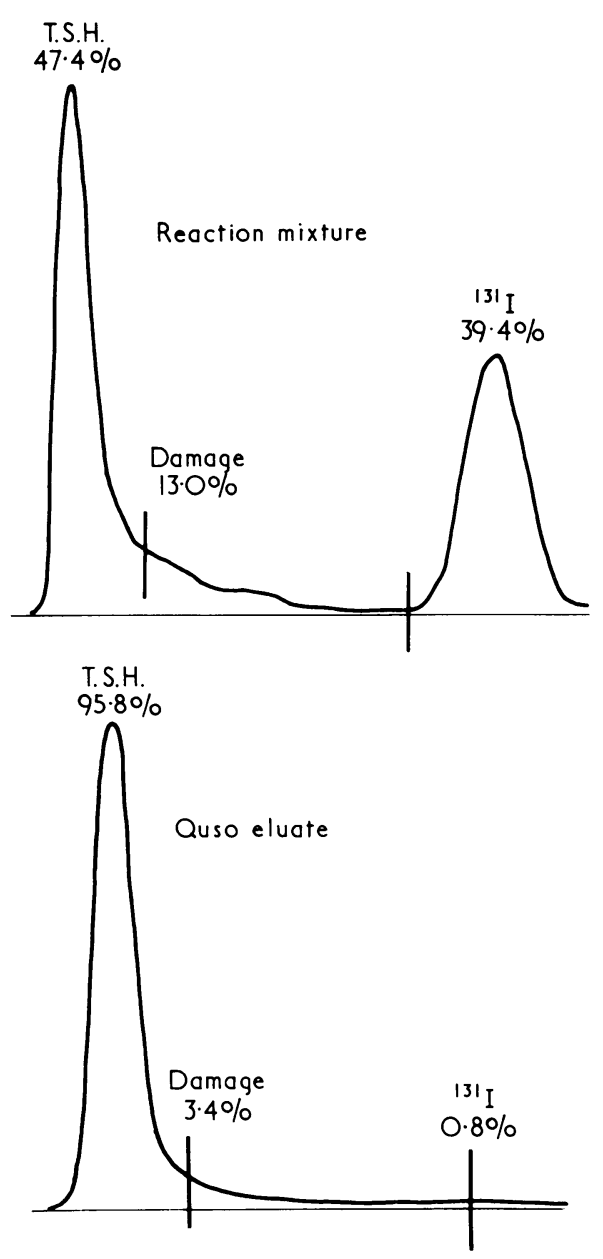

FIG. 1-Electrophoresis at $500 \mathrm{~V}$ for one hour (in $0.05 \mathrm{M}$ barbitone buffer, pH 8.6) showing reaction mixture (131I-TSH $47.4 \%$, damage $13.0 \%,{ }_{131} \mathrm{I} 39.4 \%$ ) and Quso eluate ( ${ }^{131} \mathrm{I}-\mathrm{T}$ TSH $95.8 \%$, damage $3.4 \%$, ${ }^{1311} 0.8 \%$ ).

times with phosphate-buffered albumin and the undamaged TSH is then eluted with $2 \mathrm{ml}$ of $40 \%$ acetone in $1 \%$ acetic acid. Fig. 1 shows an electrophoretogram of the original iodination mixture and of the final Quso eluate of relatively undamaged ${ }^{131}$-I-TSH. Specific activity of ${ }^{131} \mathrm{I}-\mathrm{TSH}$ ranges from 200 to $300 \mu \mathrm{Ci} / \mu \mathrm{g}$.

Assay Procedure.-The incubation volume of $0.6 \mathrm{ml}$ in each assay tube is made up of $0.1 \mathrm{ml} 0.1 \mathrm{M}$ EDTA, $0.1 \mathrm{ml}$ guinea-pig anti-TSH serum $(1 / 100,000$ dilution, final dilution $1 / 600,000)$, $0.1 \mathrm{ml}$ human chorionic gonadotrophin (10 IU), $0.2 \mathrm{ml}$ test serum or standard TSH made up in serum from subjects treated for eight days with $120 \mu \mathrm{g}$ daily of triiodothyronine $(\mathrm{T}-3)$. Sera from hypothyroid subjects is diluted in T-3-suppressed serum. After two days' preincubation $100 \mathrm{pg}$ of ${ }^{131} \mathrm{I}-\mathrm{TSH}$ is added and the incubation continues at $4^{\circ} \mathrm{C}$ for five days when second antibody is added. After a further 24 hours the precipitate is separated by centrifugation and counted in a Nuclear Chicago Autogamma Counter. Quality control is maintained by the method of Rodbard et al. (1968) and the following criteria must be satisfied for an acceptable assay: (1) more than $40 \%$ of the label in the iodination mixture is in the initial protein peak at the origin of the electrophoretogram; (2) excess antiserum must precipitate $>85 \%$ label; (3) in the absence of antiserum $<5 \%$ label is precipitated;

TSH Levels ( $\mu U / \mathrm{ml}$ of M.R.C. Standard A H-TSH)

\begin{tabular}{ll|c|c|c|c}
\hline & Mean & Range & S.D. & Number \\
\hline Normal controls &. & 1.6 & $0.6 *-4.2$ & \pm 0.8 & 29 \\
Hyperthyroidism & $\cdots$ & 1.0 & $0.5-1.9$ & \pm 0.4 & 18 \\
Hypothyroidism & $\cdots$ & 177 & $6.5-588$ & \pm 152 & 19 \\
Non-toxic goitre & 1.7 & $0.5-2.7$ & +0.5 & 31 \\
Acromegaly (no goitre) & 1.8 & $0.5-3.0$ & +0.8 & 13 \\
\hline
\end{tabular}

* In 2 normal controls TSH $<0.5$
(4) control serum values do not differ significantly from previous assays (two normal sera, two hypothyroid sera); (5) there is no flattening of the origin of the standard curve; and (6) the percentage of label bound without added standard TSH should not fall below $45 \%$.

\section{Results}

Sensitivity.-This is defined as the smallest amount of unlabelled hormone which can be distinguished from no hormone. The sensitivity of our current assay is in the region of $0.5 \mu \mathrm{U} \mathrm{TSH} / \mathrm{ml}$, a $10 \%$ fall in the percentage bound in the standard curve is achieved with $1-2 \mu \mathrm{U} / \mathrm{ml}$. This degree of sensitivity is sufficient to allow the detection of serum TSH levels in most normal subjects.

Specificity.-Unlike most rabbit anti-TSH sera the guineapig antiserum shows no cross-reaction with human chorionic gonadotrophin but cross reacts to a small extent with bovine TSH. We have continued to add human chorionic gonadotrophin to our system to maintain constancy of the incubation medium with previous assays where antisera cross-reacting with human chorionic gonadotrophin were used. None of the antisera tested showed any cross-reaction with human growth hormone or corticotrophin.

TSH Levels.-Serum TSH levels in normal subjects and in parients with hyperthyroidism, hypothyroidism, non-toxic goitre, and acromegaly are shown in the Table. In only 2 out of 29 normal subjects was the serum TSH level undetectable. Patients with hyperthyroidism have significantly lower TSH levels, though occasional values fall in the normal range. TSH levels have been raised in all subjects with hypothyroidism due to primary thyroid disease that have been tested so far. In patients with non-toxic goitre without autoimmune thyroid disease TSH levels are found to be within the normal range. Patients with acromegaly have normal TSH levels even in the presence of thyroid enlargement.

Potential Stimuli to TSH Release.-TSH levels did not rise in response to an antithyroid drug carbimazole, 40 $\mathrm{mg}$ daily for one month (three subjects), lysine vasopressin, 10 pressor units intravenously over two hours (five subjects), and acute lowering of the central body temperature by $3.6^{\circ} \mathrm{F}$ $\left(2^{\circ} \mathrm{C}\right)$ in one subject. Using our current more sensitive TSH assay we have been able to show a rise in serum TSH levels in response to a combination of carbimazole ( $40 \mathrm{mg}$ daily) along with potassium iodide (60 mg daily) within one week in all five normal male volunteers (aged 24 to 26 years) who were tested (Fig. 2). Synthetic thyrotrophin releasing hormone in doses of $50 \mu \mathrm{g}$ and above intravenously also causes a

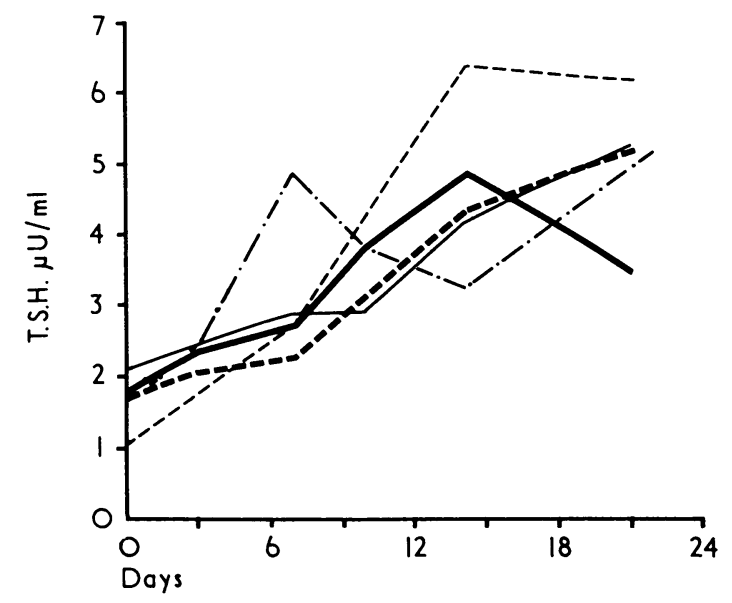

HIG. 2-Effect of carbimazole (40 $\mathrm{mg}$ daily) and iodides (60 mg daily) on serum TSH levels in five men. 
rise in serum TSH levels (Hall et al., 1970b). Since the preliminary report of Adams and Maloof (1970) that oestrogens cause a rise in circulating TSH we have administered ethinyloestradiol $1 \mathrm{mg}$ orally to five normal adult male volunteers. A rise in TSH was detectable in only one of them (from 1.8 to $4.9 \mu \mathrm{U} / \mathrm{ml}, 33$ hours after administration of the hormone).

\section{Discussion}

The double antibody radioimmunoassay for serum TSH described by Odell et al. (1965) is a straightforward procedure. Unlike corticotrophin and parathyroid hormone, ${ }^{131}$ I-TSH seems comparatively stable and resistant to incubation damage. The use of the Quso method allows rapid purification of the labelled hormone without the need for column separation. The main problem has been to obtain maximal sensitivity of the assay since normal TSH levels are probably $<1 \mu \mathrm{U} / \mathrm{ml}$. Raud and Odell (1969) reported TSH levels in normal subjects of $1.8-10.0$ (mean 4.9) $\mu \mathrm{U} / \mathrm{ml}$ (M.R.C. Standard A), and Hall et al. (1970a), using a similar rabbit antiserum, found levels of $1-10.4$ (mean 4.8 ) $\mu \mathrm{U} / \mathrm{ml}$, using the same standard. Our current assay with a guinea-pig antiserum gives normal TSH levels lower than either of the previous series. In an effort to define the normal level of serum TSH, Hall and Amos (1971) administered T-3 $120 \mu \mathrm{g}$ daily to 10 normal adults (4 men, 6 women). A highly significant fall in serum TSH resulted, the mean decrease being $0.85 \mu \mathrm{U} / \mathrm{ml}$. It was suggested that this value might give some approximation to the normal TSH level, any residual TSH measured after $\mathrm{T}-3$ representing a non-specific component varying in different serum specimens. This compares with the TSH level of 0.66 (range $0.3-0.9) \mu \mathrm{U} / \mathrm{ml}$ obtained by Adams $e t$ al. (1970) after extraction and concentration (twentyfold) of plasma from normal subjects before immunoassay.

In hyperthyroidism all workers apart from Lemarchand Béraud et al. (1970) have reported lowered levels of serum TSH as would be expected since the thyroid overactivity is now considered to derive from an extrapituitary thyroidstimulating immunoglobulin, the long-acting thyroid stimulator. Tests on some 50 patients with pituitary tumours, either chromophobe or eosinophil in origin, have failed to show a rise in TSH, except in two subjects with hypothyroidism due to a lingual thyr id who had secondary enlargement of the pituitary fossa and very high TSH levels. Like Raud and Odell (1969), we have yet to observe a patient with hyperthyroidism caused by a pituitary tumour producing excess TSH, though Hamilton et al. (1970) reported hyperthyroidism associated with raised serum TSH levels in a man with a chromophobe adenoma of the pituitary.

All patients with hypothyroidism so far tested have had raised levels of TSH often when conventional tests of thyroid function such as the serum protein-bound iodine, the Thyopac-3 test, and the 24-hour thyroidal uptake of ${ }^{131}$ I were in the so-called normal range. The rise in serum TSH correlates well with a failure of the thyroidal radioiodine uptake to rise in response to administered TSH. It is in the diagnosis of minor degrees of thyroid hormone deficiency that the TSH assay has its major clinical application, particularly in children where the diagnosis can be difficult.

The finding of normal serum TSH levels in non-toxic goitre not associated with autoimmune thyroiditis accords with the findings of Odell et al. (1967) but differs from the results of Lemarchand Béraud and Vanotti (1965), who found values to be slightly higher than normal. Though the aetiology of most cases of non-toxic goitre in the U.K. is at present uncertain it has been asserted that "all types of goitre are due to increased TSH stimulation, although it is not yet known whether this increased TSH stimulation persists or not when a compensated stage has been reached" (Wayne et al., 1964). Likewise the failure of suppressive therapy with thyroid hormone to produce improvement in some goitres in this country has been attributed to the development of irreversible nodular changes. An alternative equally plausible hypothesis is that some goitres do not result from partial failure of thyroid hormone production but from a defect of intrathyroidal regulation possibly akin to the reparative growth of thyroid grafts after implantation which is known to occur in the absence of TSH (Doniach, 1960).

The finding of normal TSH levels in acromegaly with and without goitre confirms the accepted view that the goitre which often accompanies this disease is due either to a direct effect of growth hormone on the thyroid or to a response to the increased tissue demands for thyroid hormone.

\section{POTENTIAL STIMULI}

A wide variety of potential stimuli to $\mathrm{TSH}$ secretion have been used in an attempt to cause release of TSH from the pituitary. No alterations in TSH levels were caused by glucose, meals, exercise, fasting, fever, surgery, cold exposure, or arginine by Odell et al. (1968) or by methimazole plus iodides, vasopressin, and glucagon by Sawin et al. (1970). Likewise in our hands carbimazole, lysine vasopressin, and acute cold exposure have failed to cause a rise in TSH. The increase in serum TSH which occurs shortly after birth cannot be prevented by control of the environmental temperature, but an increase in TSH can be stimulated by delayed cooling (three to four hours after birth), indicating that cooling at this time is an effective stimulus (Fisher and Odell, 1969). Again, in adults prolonged exposure to a cold environment does cause a small rise in TSH level (Raud and Odell, 1969). Elevation of plasma TSH has also been reported in $6 / 7$ infants, aged 1.5-13 months, during hypothermic cardiovascular surgery (Wilber and Baum, 1970).

Because carbimazole alone failed to cause a fall in serum protein-bound iodine or a rise in TSH in three normal controls we studied the effect of adding a large dose of potassium iodide to the carbimazole regimen. Mercer et al. (1960) showed that iodides slow the rate of thyroid secretion in euthyroid people. We therefore planned to block further formation of thyroid hormone with carbimazole while slowing the rate of secretion of preformed hormone by the use of iodides. The prompt rise of serum TSH levels in all five subjects confirms that we achieved this objective, presumably by lowering the circulating level of thyroid hormones. Previous suggestions that iodides have an action on the pituitary as well as on the thyroid (Greer and DeGroot, 1956) seem unlikely in view of the rise in TSH resulting from iodides administration.

The advent of synthetic thyrotrophin-releasing hormone has now provided a potent stimulus to TSH release (Bowers et al., 1970; Fleischer et al., 1970; Hall et al., 1970b). Measurements of serum TSH after intravenous thyrotrophinreleasing hormone also help in the diagnosis of pituitary TSH deficiency (Fleischer et al., 1970).

The report by Adams and Maloof (1970) that ethinyloestradiol administered to men and hypogonadal women causes a threefold to tenfold increase in serum TSH some 24 to 36 hours later without changes in serum thvroxine requires further study. We have observed a rise in TSH in only one out of five men tested so far. Nicoloff et al. (1970) reported that oestrogens act directly on the thyroid, inhibiting release of thyroid hormone as well as causing a prompt suppression of serum TSH levels. Further studies are reouired to resolve the discrepancies in these reports. Fluctuations of TSH levels and thyroid secretion in response to variations in oestrogen production might have important implications in the pathogenesis of goitre. 
This work was supported by grants from the Wellcome Trust, the North of England Council of the British Empire Cancer Campaign, and the Scientific and Research Subcommittee of the Royal Victoria Infirmary. The advice of Professor G. A. Smart, Professor A. L. Latner, and Dr. F. Clark and the technical assistance of Mrs. A. Hewison are gratefully acknowledged. Human TSH for iodination was provided by the National Pituitary Agency and Endocrinology Study Section of the National Institute of Arthritis and Metabolic Disease, human TSH as standard A was supplied by Dr. R. Bangham, of the National Institute for Medical Research, and human TSH for immunization purposes was provided by Dr. A. Hartree.

\section{References}

Adams, D. D., Kennedy, T. H., and Utiger, R. D. (1970). Abstracts of the Sixth International Thyroid Conference, Vienna

Adams, L., and Maloof, F. (1970). Fournal of Clinical Investigation, 49, 1a. Bowers, C. Y., et al. (1970). Biochemical and Biophysical Research Communications, 39, 352

Doniach, I. (1960). British Medical Bulletin, 16, 99.

Fisher, D. A., and Odell, W. D. (1969). Journal of Clinical Investigation, 48, 1670.

Fleischer, N., Burgus, R., Vale, W., Dunn, T., and Guillemin, R. (1970). Fournal of Clinical Endocrinology and Metabolism, 31, 109

Greer M. A and DeGroot, L. J. (1956). Metabolism, 5, 682.

Hall, R., and Amos, J. (1971). In Radioimmunoassay Methods, ed. K. E. Kirkham and W. M. Hunter. To be published.

Hall, R. Tubmen, J., and Garry, R. (1970a). Clinical Science, 38, 18P

Hall, R., Amos, J., Garry, R., and Buxton, R. L. (1970b). British Medical fournal, 2, 274.
Hamilton, C. I., Adams, L. C., and Maloof, F. (1970). New England Fournal of Medicine, 283, 1077.

Hunter, W. M., and Greenwood, F. C. (1962). Nature, 194, 495.

Kirkham, K. E., Hunter, W. M., Jeffery, F. H., and Bennie, J. G. (1970) In In Vitro Procedures with Radioisotopes in Medicine. Vienna, International Atomic Energy Agency.

Lemarchand Béraud, Th., Griessen, M., and Scazziga, B. R. (1970). Abstracts of the Sixth International Thyroid Conference, Vienna.

Lemarchand Béraud, Th., and Vanotti, A. (1965). In Current Topics in Thyroid Research, ed. C. Cassano and M. Andreoli, p. 527. New York, Academic Press.

Mercer, C. J., Sharard, A., Westerink, C. J. M., and Adams, D. D. (1960). Lancet, $2,19$.

Nicoloff, J. T., Gross, H. A., and Appleman, D. (1970). Abstracts of the Sixth International Thyroid Conference, Vienna.

Odell, W. D., Wilber, J. F., and Paul, W. E. (1965). Fournal of Clinical Endocrinology and Metabolism, 25, 1179.

Odell, W. D., Utiger, R. D., and Wilber, J. F. (1967). Recent Progress in Hormone Research, 23, 47 .

Odell, W. D., Vanslager, D. L., and Bates, R. (1968). In Radioisotopes in Medicine: In Vitro Studies, ed. R. L. Hayes, F. A. Goswitz, and B. E. P. Murphy, p. 185. Oak Ridge, Tennessee, U.S. Atomic Energy Commission

Raud, H. R., and Odell, W. D. (1969). British Fournal of Hospital Medicine,

2, 1366.
Rodbard, D., Rayford, P. L., Cooper, J. A., and Ross, G. T. (1968). fournal of Clinical Endocrinology and Metabolism, 28, 1412.

Sawin, C. T., Hershman, J. M., Handler, S. D., and Utiger, R. D. (1970). Metabolism, 19, 488.

Utiger, R. D. (1965). Fournal of Clinical Investigation, 44, 1277.

Wayne, E. J., Koutras, D. A., and Alexander, W. D. (1964). Clinical Aspects of Iodine Metabolism, p. 102. Oxford, Blackwell Scientific.

Webster, B. R., and Greenwood, F. C. (1968). In Protein and Polypeptide Hormones, ed. M. Margoulies, p. 32. Amsterdam, Excerpta Medica Foundation.

Wilber, J. F., and Baum, D. (1970). Journac of Clinical Endocrinology and Metabolism, 31, 372

Yalow, R. S., and Berson, S. A. (1966). Nature, 212, 357.

\title{
Diazepam and Tests of Thyroid Function
}

\author{
FREDERICK CLARK, REGINALD HALL， BRIAN J. ORMSTON
}

British Medical fournal, 1971, 1, 585-586

\section{Summary}

The effect of diazepam on thyroid function tests was examined in 12 euthyroid patients requiring the drug for psychiatric reasons and in six patients with thyrotoxicosis. Assessment was made before and after four weeks' therapy.

There was no significant difference in results from tests of thyroid iodide trapping and binding (thyroid radioiodine uptake, thyroid clearance, and absolute iodine uptake) except in the one-hour thyroid uptake in the euthyroid group, which was increased after diazepam. This increase occurred without alteration in serum thyroid stimulating hormone levels. No change occurred in either group in tests of thyroid hormone release (protein-bound iodine, T-3 resin uptake, or Thyopac-3 and free thyroxine index).

Patients with suspected thyroid disease who are taking diazepam do not need to stop therapy while their thyroid status is being determined.

Newcastle General Hospital, Newcastle upon Tyne NE4 6BE FREDERICK CLARK, M.B., M.R.C.P., Consultant Physician, and Lecturer in Clinical Medicine, University of Newcastle upon Tyne

\section{Royal Victoria Infirmary, Newcastle upon Tyne NE1 4LP}

REGINALD HALL, M.D., F.R.C.P., Consultant Physician, and Professor of Medicine, University of Newcastle upon Tyne

BRIAN J. ORMSTON, M.B., B.S., Research Fellow in Medicine

\section{Introduction}

Since the report that diazepam (Valium) caused depression of thyroid uptake of ${ }^{131}$ I (Harvey, 1967), statements have appeared in the literature which tend to perpetuate this belief (Today's Drugs, 1969; Walton and Thompson, 1969; Year Book of Drug Therapy, 1970). Earlier, Schindler et al. (1966) had failed to show any effect of the drug on pituitary thyroid stimulating hormone (TSH) release or thyroid gland activity in the mouse, and in a double-blind placebo controlled study in normal volunteers Mazzaferri and Skillman (1969) were unable to substantiate any change in thyroid function after diazepam. Likewise, Greenberg et al. (1970) could find no effect on laboratory measurements of thyroid function in three patients with thyrotoxicosis. In in-vitro experiments interference by diazepam with the estimation of protein-bound iodine (P.B.I.) which led to falsely raised values has been noted (Tegeris $e t$ al., 1969). The concentration of diazepam used, however, was considerably higher than would be expected in clinical usage.

In view of these conflicting reports, and as diazepam is a commonly prescribed drug, it was considered that additional examination was necessary to ascertain the effect, if any, of the agent on commonly used tests of thyroid function in cuthyroid and thyrotoxic individuals.

\section{Subjects and Methods}

These were similar to those used for chlordiazepoxide (Clark and Hall, 1970). Twelve euthyroid patients (11 women and 1 man, aged 29 to 54 years) and six patients with thyrotoxicosis (all women, aged 28 to 49) were tested before and after four iveeks of therapy with diazepam $5 \mathrm{mg}$ three times a day. The 